\title{
Soluble interleukin 2 receptors in autoimmune chronic active hepatitis
}

\author{
A Lobo-Yeo, G Mieli-Vergani, A P Mowat, D Vergani
}

\begin{abstract}
Children with uncontrolled autoimmune chronic active hepatitis have increased numbers of activated $T$ lymphocytes expressing interleukin 2 receptors (IL2R). A soluble form of IL2R has recently been described whose proposed role is to downregulate $T$ cell activation by competing for interleukin 2 . We investigated whether a deficiency of soluble IL2R could account for the high concentrations of IL2R positive $T$ lymphocytes in autoimmune chronic active hepatitis. Soluble IL2R was measured by enzyme-linked immunosorbent assay in the serum of 16 children with autoimmune chronic active hepatitis, eight with chronic liver disease due to hepatitis $B$ virus infection, seven with Wilson's disease, nine with $\alpha_{1}$ antitrypsin deficiency, and 15 healthy age matched controls. Soluble IL2R concentration was significantly higher in patients with autoimmune chronic active hepatitis than in healthy controls (mean (SEM) 475 (75) U/ml, 145 (8) U/ml respectively, p $<0.01)$. Eleven patients who had active disease had significantly higher soluble IL2R concentrations $(590(89) \mathrm{U} / \mathrm{ml})$ than the five cases with inactive disease $(220(36) \mathrm{U} / \mathrm{ml}$, $\mathbf{p}<0.01)$. No difference was found between the controls and the patients with chronic liver disease due to hepatitis $B$ infection, Wilson's disease, and $\alpha_{1}$ antitrypsin deficiency. Percentages and absolute numbers of surface IL2R positive $T$ cells as detected by immunofluorescence were significantly higher in the patients with autoimmune chronic active hepatitis $(11.8 \%(1) ; 274 / \mu 1(31))$ than in controls $(0.2 \%(0.1) ; 5 / \mu l(2), p<0.001)$, the highest values being found in those with uncontrolled disease. A significantly positive correlation was observed between concentrations of soluble IL2R and the percentage of $T$ cells expressing IL2 receptors ( $r=0.67$, $p<0.001)$. These results indicate that the high levels of IL2R positive T lymphocytes characteristic of autoimmune chronic active hepatitis are not due to a deficiency of soluble IL2 receptors.
\end{abstract}

Autoimmune chronic active hepatitis is characterised by progressive liver damage associated with autoimmune reactions to specific liver antigens. ${ }^{1-3}$ We have previously shown appreciably increased concentrations of circulating activated $\mathrm{T}$ lymphocytes expressing receptors for interleukin 2 (IL2R) on their surface during periods of uncontrolled disease activity. Interleukin 2 is released by $T$ cells and has a pivotal role in the control of immune responses, since, in the presence of antigen, it leads to proliferation and differentiation of antigen specific $T$ cell clones. ${ }^{5}$

It has recently been shown that soluble IL2R is present in the circulation of normal subjects in low concentrations and is increased in patients with diseases characterised by immunodeficiency such as lymphoreticular disorders. ${ }^{6}$ It has therefore been suggested that soluble IL2R regulates $T$ cell activation by competing for interleukin 2 , thus abrogating the proliferation of activated $\mathrm{T}$ cells. An excessive production would lead to immunodeficiency states, a deficiency to autoimmunity. ${ }^{6}$ The aim of this study was to investigate whether deficiency of the circulating form of IL2R could provide an explanation for the high levels of activated $T$ cells found in autoimmune chronic active hepatitis and be responsible for the uncontrolled autoaggression characteristic of this disease.

\section{Patients}

All the patients studied were consecutive cases attending the paediatric liver service, during June 1984 and May 1986. Sixteen patients had autoimmune chronic active hepatitis that had started in childhood ( 12 females, age range 4-18 years, median 12.5 years). At diagnosis they all had increased levels of aspartate aminotransferase (median $450 \mathrm{IU} / \mathrm{l}$, range 140-2150 IU/l; normal < $45 \mathrm{IU} / \mathrm{l})$ and serum IgG $(28 \mathrm{~g} / \mathrm{l}, 19-52$ $\mathrm{g} / \mathrm{l}$; normal range at $3-5$ years $5-16 \cdot 5 \mathrm{~g} / \mathrm{l}$, at $5-18$ years $6 \cdot 5-18 \mathrm{~g} / \mathrm{l}$ ), high titres of one or more nonorgan specific autoantibodies (antinuclear antibody, smooth muscle antibody, and liver kidney microsomal antibody $>1: 40$ ), and severe piecemeal necrosis and portal tract infiltration in the liver biopsy speciman. ${ }^{7}$ Six patients were investigated at diagnosis, before starting treatment, while 10 were receiving immunosuppressive treatment at the time of study. Eight were receiving prednisolone alone $(0.5-2 \mathrm{mg} / \mathrm{kg}$ per day) and two prednisolone $(0.5-1 \mathrm{mg} / \mathrm{kg}$ per day) and azathioprine ( $1 \mathrm{mg} / \mathrm{kg}$ per day). The disease was considered to be uncontrolled by treatment if they had histological inflammatory activity (documented in four patients) or, in the absence of liver biopsy, if they had an aspartate amino- 


\begin{tabular}{|c|c|c|c|c|c|c|c|}
\hline \multirow[b]{2}{*}{ Diagnosis (No of patients) } & \multirow{2}{*}{$\begin{array}{l}\text { Age } \\
\text { (years) }\end{array}$} & \multirow{2}{*}{$\begin{array}{l}\text { Duration } \\
\text { of disease } \\
\text { (years) }\end{array}$} & \multirow{2}{*}{$\begin{array}{l}\text { Aspartate } \\
\text { aminotransferase } \\
(\text { IU/l) }\end{array}$} & \multirow[b]{2}{*}{$I g G \dagger(g / l)$} & \multicolumn{3}{|c|}{$\begin{array}{l}\text { Autoantibodies } \ddagger \\
\text { (No of patients) }\end{array}$} \\
\hline & & & & & $S M A$ & $A N A$ & $L K M$ \\
\hline Autoimmune chronic active hepatitis - active (11) & $12(4-18)$ & $0 \cdot 6(0 \cdot 1-8)$ & $340(95-1470)$ & $25(13-40)$ & 5 & 3 & 2 \\
\hline Autoimmune chronic active hepatitis - inactive (5) & $12(6-14)$ & $3(1-8)$ & $29(19-48)$ & $13(7-15)$ & 1 & 0 & 1 \\
\hline Chronic liver disease due to hepatitis B infection (8) & $6.5(2-12)$ & $1(0 \cdot 2-2)$ & $133(19 \cdot 605)$ & $12(8-19)$ & neg & neg & neg \\
\hline Wilson's disease (7) & $14(6-18)$ & $3 \cdot 5(0 \cdot 1-6)$ & $40(13-220)$ & $13(10-19)$ & neg & neg & neg \\
\hline$\alpha_{1}$ antitrypsin deficiency (9) & $7(2-13)$ & $1(0 \cdot 3-6)$ & $92(40-299)$ & $10(5-16)$ & neg & neg & neg \\
\hline
\end{tabular}

^Normal $<45$ IU/1

†Normal range $3-5$ years $5 \cdot 2-16 \cdot 5 \mathrm{~g} / 1 ; 5-18$ years $6 \cdot 5-18 \mathrm{~g} / 1$

¥SMA = mooth muscle antibody; ANA = antinuclear antibody; LKM=liver kidney microsomal antibody (all at a titre $>1: 40$ ).

transferase level of more than twice the upper limit of normal in association with raised IgG levels or autoantibodies at titres of $>1: 40$ or both (Table).

Eight patients with chronic liver disease due to hepatitis $B$ virus infection were also studied (seven males, age range 2-12 years, median 6.5 years). Four were $\mathrm{HBe}$ antigen positive, one of whom was also IgM delta antibody positive, and three were $\mathrm{HBe}$ antigen negative, $\mathrm{HBe}$ antibody positive. Seven were studied at the time a liver biopsy specimen was taken, six having chronic active hepatitis and one chronic persistent hepatitis. The remaining child was diagnosed as having chronic active hepatitis three years earlier but had normal liver function tests at the time of study. None of these patients was treated.

Sixteen patients with chronic liver disease due to genetic causes were also studied. Seven had Wilson's disease (five males, age range 6-18 years, median 14 years) and nine $\alpha_{1}$ antitrypsin deficiency (five males, age range 2-11 years, median 5 years). At the time of study five patients with Wilson's disease were treated with penicillamine $(20 \mathrm{mg} / \mathrm{kg}$ per day). Five patients (three with Wilson's disease, two with $\alpha_{1}$ antitrypsin deficiency) had active disease as assessed by inflammatory changes in the liver biopsy specimen and an increase in aspartate aminotransferase of more than twice the upper limit of normal.

All patients with autoimmune chronic active hepatitis, Wilson's disease, and $\alpha_{1}$ antitrypsin deficiency were negative for the hepatitis $B$ surface antigen (HBsAg) and for anti-HBc.

During the study 15 healthy children (eight females, age range 4-18 years, median 12 years) were recruited as normal controls. Informed consent was obtained from the parents and older children.

\section{Methods}

SOLUBLE IL $2 R$ IN SERUM

The enzyme-linked immunosorbent assay for soluble IL2R was performed using an Interleukin-2 Receptor Test (CELLFREE, T Cell Sciences, Cambridge MA, USA), based on two monoclonal antibodies (anti-Tac and 7G7/B6) directed against non-overlapping epitopes on human IL2R. ${ }^{69}$ Serum IL2R concentrations are expressed in $\mathrm{U} / \mathrm{ml} ; 1000$ units is the amount of released soluble IL2R present in $1.0 \mathrm{ml}$ of a T Cell Sciences' Reference Preparation of supernatant from phytohaemagglutinin stimulated peripheral blood lymphocytes
(CELLFREE, T Cell Sciences, Cambridge MA). A standard curve was established using the reference preparation.

IDENTIFICATION OF IL $2 R$ ON T CELLS IL2R positive $T$ lymphocytes were identified using a technique described in detail previously. ${ }^{+}$ Briefly, T lymphocytes were purified by rosetting with neuraminidase treated sheep red blood cells. IL2R was detected using anti-Tac monoclonal antibody (kindly provided by Dr T A Waldmann) in an indirect immunofluorescence assay. $T$ lymphocytes were incubated with a 1:5000 dilution of anti-Tac for $40 \mathrm{~min}$ at $4^{\circ} \mathrm{C}$, washed, and then incubated with FITC conjugated rabbit anti-mouse immunoglobulin for 30 min at $4^{\circ} \mathrm{C}$. The cells were then washed and examined under ultraviolet microscopy. Four hundred cells were counted by an observer unaware of the clinical details. The number of positive cells against the total gave the percentage positivity.

\section{HEPATITIS B MARKERS}

$\mathrm{HBsAg}$, anti-HBc, HBeAg, anti-HBe, and IgM anti-delta antigen were measured by radioimmunoassay (Ausria, Corab, HBe RIA, Abbott; anti-delta, Mercia Diagnostics).

\section{NON-ORGAN SPECIFIC AUTOANTIBODIES}

Non-organ specific autoantibodies were detected by indirect immunofluorescence technique using rat liver, kidney, and stomach as substrate. ${ }^{10}$

\section{STATISTICS}

Results expressed as mean (standard error of the mean) were compared by Student's $t$ test (two tailed). Results were considered significant at $\mathrm{p}<0 \cdot 05$. All tests were repeated using Wilcoxon's rank sum test and the levels of significance were similar. To ascertain whether the difference in the female to male ratio between patients and normal controls could affect the results statistical analysis was repeated, dividing the control subjects into two groups according to sex. Correlations were obtained using Spearman linear regression analysis.

\section{Results}

SOLUBLE IL $2 R$

The amount of soluble IL2R in serum was 


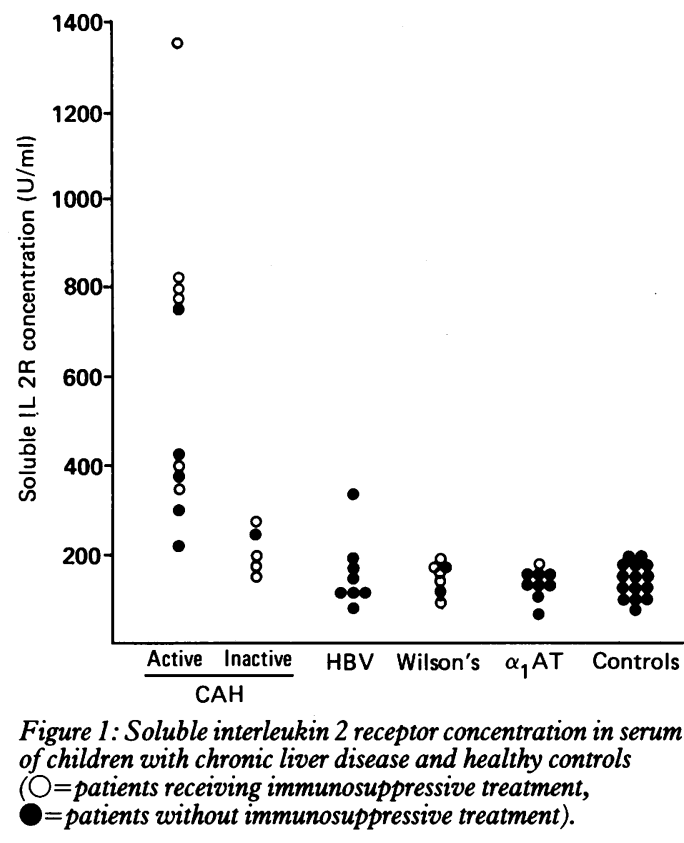

significantly higher in patients with autoimmune chronic active hepatitis (mean (SEM) 475 (75) $\mathrm{U} / \mathrm{ml}$ ) than in the healthy controls $(145(8) \mathrm{U} / \mathrm{ml}$, $\mathrm{p}<0.01$ ), while no difference was found between controls and the eight patients with chronic liver disease due to hepatitis $B$ infection, the seven patients with Wilson's disease, and the nine patients with $\alpha_{1}$ antitrypsin deficiency irrespective of disease activity (166 (28); $142(11) ; 130$ (9) $\mathrm{U} / \mathrm{ml}$ respectively, not significant) (Fig 1 ).

The eleven patients with autoimmune chronic active hepatitis and active disease had significantly higher concentrations of soluble IL2R (590 (89) $\mathrm{U} / \mathrm{ml}$ ) than the five with inactive disease $(220$ (36), p<0.01). Patients with inactive disease had significantly higher values than controls $(p<0 \cdot 04)$. The ranges of values obtained in active and inactive disease were almost completely distinct, only one patient with inactive disease having levels similar to those found in active disease.

IL 2R RECEPTORS ON T LYMPHOYTES The percentage (Fig 2) and absolute numbers of

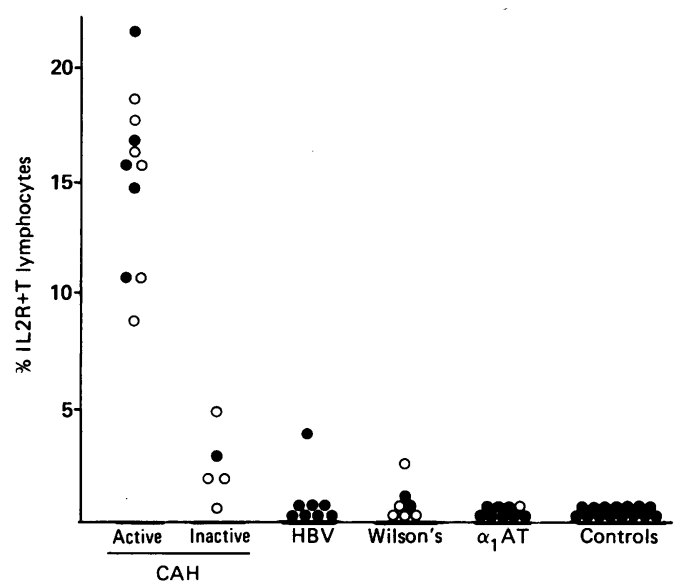

Figure 2: Percentage of circulating $T$ lymphocytes expressing interleukin 2 receptors in children with chronic liver disease and healthy controls $\mathrm{O} O=$ patients receiving immunosuppressive treatment, $\bigcirc=$ patients without immunosuppressive treatment)

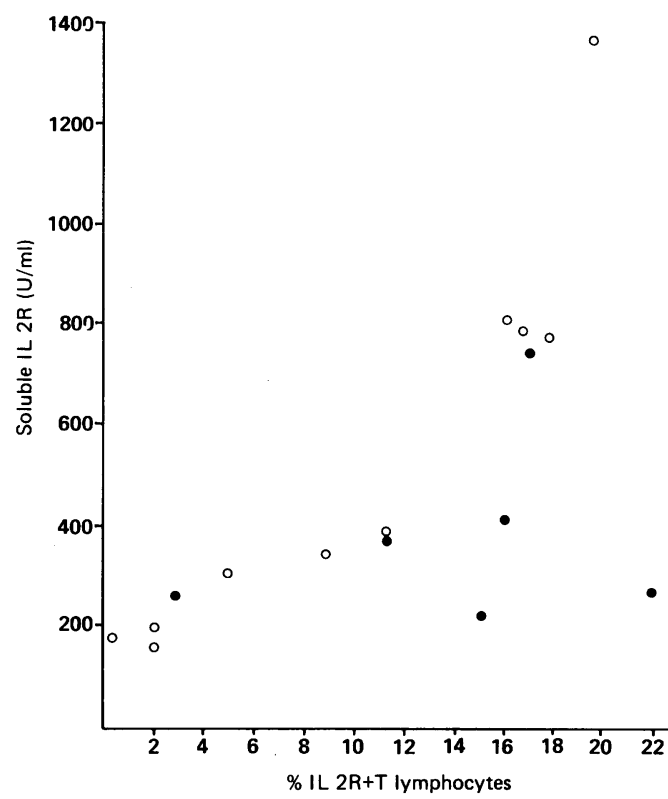

Figure 3: Correlation between concentrations of soluble interleukin 2 receptors and percentage of circulating $T$ lymphocytes expressing interleukin 2 receptors in patients with autoimmune chronic active hepatitis $(\mathbf{O}=$ untreated $\mathrm{O}=$ treated).

Tac (IL2R) positive cells were significantly higher in the 16 patients with chronic active hepatitis $(11 \cdot 8 \%(1 \cdot 0) ; 274 / \mu \mathrm{l}(31))$ than in 15 healthy subjects $(0 \cdot 2 \%(0 \cdot 1) ; 5 / \mu \mathrm{l}(2)), \mathrm{p}<0 \cdot 001)$ while no difference was found between controls and patients with chronic liver disease due to hepatitis B infection $(0.6 \%(0.4) ; 13 / \mu l(7))$, Wilson's disease $(0 \cdot 4 \%(0.3) ; 9 / \mu \mathrm{l}(6))$, or $\alpha_{1}$ antitrypsin deficiency $(0 \cdot 2 \%(0 \cdot 1) ; 3 / \mu \mathrm{l}(2))$. The eleven patients with uncontrolled autoimmune chronic active hepatitis had significantly higher values $(16 \cdot 2 \%(1 \cdot 1) ; 356 / \mu \mathrm{l}(38))$ than the five with inactive disease $(2 \cdot 1 \%(0 \cdot 9) ; 48 / \mu \mathrm{l}(26)$, $\mathrm{p}<0.001)$.

When statistical analysis was repeated using only female patients and controls the difference in results was similarly significant.

RELATION BETWEEN SOLUBLE IL 2R AND IL 2 R ON T CELLS

A highly significant positive correlation was observed between the concentration of soluble IL2R and the percentage of $T$ lymphocytes expressing the IL2R $(r=0.827, p<0.001)$. When the results for patients with autoimmune chronic active hepatitis (Fig 3) were analysed separately the positive correlation still held true $(r=0.67$, $\mathrm{p}<0.001$ ).

\section{Discussion}

Our results show that concentrations of soluble IL2 $R$ are increased in autoimmune chronic active hepatitis, particularly when the disease is active, and that this increase is closely correlated with a rise in the number of activated T lymphocytes expressing the IL2R. This indicates that the high level of IL2R positive T lymphocytes is not due to a deficiency of soluble IL2R and that circulating IL2Rs are likely to be released by activated $T$ cells. Thus the hypothesis that autoimmunity derives from an inadequate con- 
centration of soluble IL2R is not supported in autoimmune chronic active hepatitis. Indeed, the possibility that soluble IL2R downregulates the immune response by competing with cell bound IL2R for interleukin 2 seems unlikely as the affinity of soluble IL2R for interleukin 2 is 10000 times lower than that of cellular IL2R (T A Waldmann, personal communication).

The increased numbers of IL2R positive T lymphocytes found in all 11 children with uncontrolled autoimmune chronic active hepatitis, who had disease of different durations, suggests that the activating stimulus is persistent. In the physiological immune response IL2R appears transiently on $\mathrm{T}$ cells after antigenic challenge. ${ }^{11}$ A persistent activation can be obtained experimentally by continuous exposure of $\mathrm{T}$ lymphocytes to the sensitising stimulus. ${ }^{12}$ Thus a sensitising antigen is likely to be constantly present in autoimmune chronic active hepatitis. IL2R expression was associated with disease activity, suggesting either that liver damage causes IL2R expression on $T$ lymphocytes or that activated $T$ cells expressing IL2R are directly involved in liver injury. No increase in IL2R positive $T$ lymphocytes was found in children with Wilson's disease or $\alpha_{1}$ antitrypsin deficiency, as shown in the present study, or in children with primary sclerosing cholangitis as previously shown, ${ }^{13}$ suggesting that in autoimmune chronic active hepatitis, IL2R positive $\mathrm{T}$ lymphocytes are unlikely to be only a consequence of liver damage but may have a pathogenic role. Interestingly, no increase in IL2R positive $T$ lymphocytes was found in seven of the eight children with chronic liver disease due to hepatitis B virus infection, the only child with increased concentrations being the one with delta infection. Thus the pattern of activation of circulating $\mathrm{T}$ lymphocytes in chronic hepatitis $\mathrm{B}$ virus infection appears to be dissimilar to that observed in children with autoimmune chronic active hepatitis. Such a discrepancy could be due to a difference in severity of liver disease in the two groups of patients, but this is unlikely since most of the children with chronic hepatitis B virus infection had disease activity comparable to that of children with autoimmune chronic active hepatitis. It is possible that in these two conditions liver damage derives from different alterations of the immunohomoeostasis. The low degree of IL2R expression in hepatitis $B$ virus related chronic liver disease may be the result of a primitive impairment of the $T$ lymphocytes to synthesise this receptor or it may be explained by the defective interleukin 2 production described in $\mathrm{HBsAg}$ positive patients, ${ }^{14}$ since interleukin 2 upregulates its own receptor. ${ }^{12}$ Inefficiency of the IL2/IL2R loop may play a part in the persistence of hepatitis B virus infection.

In autoimmune chronic active hepatitis the rise in IL2 receptor positive T cells may indicate the inability of the immune system to operate an adequate downregulation, which may derive from genetic influence. This is supported by the observation that such patients are unable to restrain liver and non-liver specific immune reactions $s^{15}$ and that similar alterations are found in their first degree relatives. ${ }^{17}$

We conclude that an increase in the number of activated $T$ lymphocytes expressing the receptor for interleukin 2 is characteristically found in patients with autoimmune chronic active hepatitis, particularly in those with poorly controlled disease. Whether these $\mathrm{T}$ lymphocytes act as orchestrators or executors of liver damage remains to be established, though this can now be studied in vitro through the clonal expansion of $T$ cells in the presence of interleukin 2 and by the analysis of antigenic specificity and function of the cloned $\mathrm{T}$ cells.

The healthy children were recruited through the Michael McGough Foundation Against Liver Disease in Children (Medway and Gillingham Branch, Kent). We thank the children and their parents for their enthusiastic participation in the study. ALY and GMV are supported by the Michael McGough Foundation Against Liver Disease in Children.

1 Eddleston ALWF, Nouri K, Hegarty JE, Alexander GJM, Williams $R$. Immunological responses in liver disease. In Williams R. Immunological responses in liver disease. In: Aol 2. Amsterdam: Excerpta Medica, 1982: 154.

2 Mackay IR. Immunological aspects of chronic active hepatitis. Hepatology 1983; 3: 724-8.

3 McFarlane IG. Autoimmunity in liver disease. Clin Sci 1984 67: 569-78.

4 Lobo-Yeo A, Alviggi L, Mieli-Vergani G, Portmann B, Mowat AP, Vergani D. Preferential activation of helper/ inducer $T$ lymphocytes in autoimmune chronic active hepatitis. Clin Exp Immunol 1987; 67: 95-104.

5 Robb RJ. Interleukin 2: the molecule and its function. Immunol Today 1984; 5: 203-9.

6 Rubin LA, Kurman CC, Fritz ME, Yarchoan R, Nelson DL. Identification and characterization of a released form of the
interleukin-2 receptor. In: Oppenheim JJ, Jacobs DM, eds. interleukin-2 receptor. In: Oppenheim JJ, Jacobs DM, eds.
Leukocytes and host defense. New York: Alan R Liss, 1986.

7 Leevy CM, Popper H, Sherlock S. Diseases of the liver and biliary tract: standardization of nomenclature, diagnostic criteria and diagnostic methodology. Sponsored by the John E Fogarty International Association for the Study of th Liver. Proceedings No 22. Washington DC: US Government Printing Office. DHEW publications no. (NIH) 76 $725,212$.

8 Rubin LA, Kurman CC, Biddison WE, Goldman MD, Nelson DL. A monoclonal antibody, $7 \mathrm{G} 7 / \mathrm{B} 6$ that binds to the human IL-2 receptor at an epitope distinct from that recognised by IL2 or anti Tac. Hybridoma 1985; 4: 91-6.

9 Rubin LA, Kurman CC, Fritz ME, et al. Soluble interleukinreceptors are released from activated lymphocytes in vitro. f Immunol 1985; 135: 3172-7.

10 Johnson GD, Holborow EJ, Dorling D. Handbook of experimental immunology. Vol 1. 3rd ed. Oxford: Blackwell mental immunology 1978 .

11 Cantrell DA, Smith KA. Transient expression of interleukin-2 receptors. F Exp Med 1983; 158: 1895-911.

12 Smith KA, Cantrell DA. Interleukin-2 regulates its own receptor. Proc Natl Acad Sci USA 1985; 82:864-8.

13 Mieli-Vergani G, Lobo-Yeo A, McFarlane BM, McFarlane IG, Mowat AP, Vergani D. Different immune mechảnisms leading to autoimmunity in primary sclerosing cholangitis and autoimmune chronic active hepatitis of childhood. Hepatology 1989; 9: 198-203.

14 Anastassakos C, Alexander GJM, Wolstencroft RA, et al. Interleukin-1 and interleukin-2 activity in chronic hepatitis B virus infection. Gastroenterology 1988; 94: 999-1005.

15 Vento S, Hegarty JE, Bottazzo GF, Macchia E, Williams R Eddleston ALWF. Antigen-specific suppressor cell function in autoimmune chronic active hepatitis. Lancet 1984; $1200-3$.

16 Nouri-Aria KT, Lobo-Yeo A, Vergani D, Mieli-Vergani G, Eddleston ALWF, Mowat AP. T suppressor cell function and number of children with liver disease. Clin Exp Immunol 1985; 61: 283-9.

17 Nouri-Aria KT, Donaldson PT, Hegarty JE, Eddleston ALWF, Williams R. HLA A1-B8-DR3 and suppressor cell ALWF, Williams R. HLA Al-B8-DR3 and suppressor cell
function in first degree relatives of patients with autoimmune chronic active hepatitis. $\mathcal{F}$ Hepatol 1985 ; 1: 235-9. 